\title{
GENETIC HISTORY OF CLASSIC PERIOD TEOTIHUACAN BURIALS IN CENTRAL MEXICO
}

\author{
Ana J. Aguirre-Samudio*, Blanca Z. González-Sobrino1, Brenda A. Álvarez-Sandoval², Rafael \\ Montiel2 $^{2}$, Carlos Serrano-Sánchez ${ }^{3}$ y Abigail Meza-Peñaloza ${ }^{3}$
}

\author{
${ }^{1}$ Laboratorio de Antropología Genética. Instituto de Investigaciones Antropológicas. Universidad Nacional Autónoma de México. \\ D. F. México \\ ${ }^{2}$ Laboratorio Nacional de Genómica para la Biodiversidad, Unidad de Genómica Avanzada, CINVESTAV-IPN. Irapuato. México \\ ${ }^{3}$ Laboratorio de Osteología. Instituto de Investigaciones Antropológicas. Universidad Nacional Autónoma de México. D. F. México
}

KEY WORDS ancient DNA; genetic analysis; mitochondrial haplogroups; prehispanic populations; barrios

\begin{abstract}
The ancient city of Teotihuacan was a great urban and ceremonial center, whose population grew exceptionally during the Classic Period (300-700 AC). Settlement patterns, culture and burials have indicated an occupation that consisted of groups of neighboring apartment compounds or barrios. We investigated the genetics of three apartment compounds in the Teotihuacan Valley through ancient DNA analysis to prove multiethnicity during the Classic Period. Amerindian mitochondrial haplogroups were identified in 10 subjects from San Francisco Mazapa, 7 from San Sebastián Xolalpan, and 19 human bone tools from La Ventilla. These samples had a wide genetic diversity. Differences in genetic structures between the three households and seven ancient populations from central and southern Mexico were slight but significant $(p<0.001)$ by $\mathrm{F}_{\text {ST }}$ analysis between the three barrios studied. Xaltocan (post-conquest) was in
\end{abstract}

agreement with the number of migrants estimated. Tlailotlacan, another Teotihuacan household, was different following a small interaction with Mazapa, Xolalpan, and La Ventilla. Through the estimation of immigrants, the three households studied seem to have come into contact with Mayans from Xcaret in Yucatan, which coincides with archaeological data reported. Genetic data could indicate that migration, along with reduced genetic drift, may possibly have a more effective role among Teotihuacan groups. This suggests that interchange with other groups did not restrict to commercial, service or governmental purposes, which implies demographic integration and genetic fusion culminating in multiethnicity during the Classic Period in Teotihuacan. Further studies can be directed to examine other households and with future sequencing analysis. Rev Arg Antrop Biol 19(1), 2017. doi:10.17139/raab.2017.0019.01.02

PALABRAS CLAVE análisis genético; ADN antiguo; haplogrupos mitocondriales; poblaciones prehispánicas; barrios

RESUMEN La ciudad de Teotihuacan tuvo un gran crecimiento poblacional durante el Período Clásico (300-700 AC, del inglés after Christ), cuando alcanzó el desarrollo urbano y llegó a ser un centro ceremonial de gran importancia. Los patrones de asentamiento, cultura y los entierros excavados muestran una ocupación organizada en barrios. En este estudio se realiza el análisis genético, por medio del $\mathrm{ADN}$ antiguo, de tres barrios ubicados en el Valle de Teotihuacan con el objetivo de identificar patrones de multietnicidad durante el Período Clásico. Se identificaron los haplogrupos mitocondriales amerindios en 10 individuos de San Francisco Mazapa, 7 de San Sebastián Xolalpan y 19 residuos de herramientas óseas de La Ventilla. Estos barrios mostraron diversidad genética. El análisis de $\mathrm{F}_{\mathrm{ST}}$ reveló poca estructura genética, pero estadísticamente significativa $(p<0.001)$, entre los barrios estudiados, en comparación

Teotihuacan has been described as a great ancestral multiethnic center of the Basin of Mexico during the Classic Period; it was an economic and political center, and an important point of interchange extending throughout Mexico and Central America (Parsons, 1987). The Teotihuacan period lasted for approximately eight centuries, before and during the powerful pre-Hispanic Period, and went from a flourishing Teotihuacan to its decay.

There were three principal settlement pat- con 7 poblaciones antiguas del centro y sur de México. En los análisis, Xaltocan fue congruente con el número de migrantes estimado. Tlailotlacan, otro barrio de Teotihuacan, tuvo una relación pequeña con los barrios estudiados. La estimación de migrantes mostró que pudieron tener contacto con mayas de Xcaret en Yucatán, en coincidencia con los datos arqueológicos reportados. Los datos genéticos podrían señalar que la migración y poca deriva genética jugaron un papel importante entre los grupos teotihuacanos, lo que sugiere intercambio con otros grupos por propósitos de comercio, servicios o gubernamentales, lo cual implica integración y fusión genética que determina multietnicidad en Teotihuacan durante el período Clásico. Estos resultados pueden ser corroborados por estudios en otros barrios de Teotihuacan y con futuros análisis de secuenciación. Rev Arg Antrop Biol 19(1), 2017. doi:10.17139/raab.2017.0019.01.02

\begin{abstract}
*Correspondence to: A. J. Aguirre-Samudio. Laboratorio de Antropología Genética. Instituto de Investigaciones Antropológicas. Universidad Nacional Autónoma de México. Av. Universidad 3000. Coyoacan 04510. D.F. México. E-mail: ajua@unam.mx
\end{abstract}

Financiamiento: Program to Support Research Projects and Technological Innovation, UNAM (PAPIIT N ${ }^{\circ}$ IN402015, IN400913); National Council of Science and Technology (CONACYT 100936).

Recibido 18 Enero 2016; aceptado 4 Julio 2016 
terns in Teotihuacan: the Pre-Classic period (Patlachique phase), from 400 to $100 \mathrm{BC}$ approximately; the Middle Horizon (Tlamimilolpa, Xolalpan, and Metepec phases), from 300 to $650 \mathrm{AC}$; and the Coyotlatelco phase, from 700 to 900 AC (Parsons, 1987; Manzanilla, 2014). Towards the late Metepec and Coyotlatelco phases, changes in ceramics represented a break in the ceramic tradition compared with early Teotihuacan (1-200 AC), which Rattray describes as catastrophic (Rattray, 1987a).

The first human occupation of the Teotihuacan Valley began in the late Pre-Classic period (400-100 BC), when inhabitants of the valley lived from the natural resources, such as corn and other plants and their derivatives, found in the surrounding areas of the San Juan river (Manzanilla, 2014). Archaeological analysis has shown cultural growth, with compounds of monumental architecture in the center, and groups of residential structures placed around them. Urban development was established in the first century (Tzacualli phase, 1-150 AC), on a territory covering an area of $4 \mathrm{~km}^{2}$, which has been identified as the biggest Pre-Classic site in central Mexico (Sanders, 1965). At some point during this period, the entire city covered a surface of over $20 \mathrm{~km}^{2}$ and was home to 20000 to 30000 inhabitants (Millon, 1973). It is possible that an increase in the number of residents in the settlements may have been one of the causes for residential re-organization. Another possibility is that it occurred owing to greater production requirements (Spence, 1987). In the following century, the Miccaotli phase (100-200 AC) was characterized by the construction of the Avenue of the Dead and the Temple of the Feathered Serpent, an important ritual center in Teotihuacan (Manzanilla, 1995). Population growth reached an estimated of 125000 inhabitants (Kurtz et al., 1987) in the Tlamimilolpa phase (250-400 AC). It was the most important demographic growth taking place in Teotihuacan, occurring in the Middle Horizon or Classic Period, and representing a large urban model (Manzanilla, 1995) designed to provide enormous supplies of food, water, and dwellings, all of which implied governmental organization and open commercial interchange. Teotihuacan culture was magnified by the Pyramid of the Moon, the Temple of the Feathered Serpent and the Great Compound in front of the Ciudadela (López Austin and López Luján, 2010).

Burials in the Teotihuacan Valley have been excavated since 1905, with numerous explorations carried out in the last century, and continuing to date (Rattray, 1997; Rodríguez Manzo, 2003). Excavations were also done in apartment compounds and multi-family residences with a number of rooms, platforms, corridors, and patios, such as Tetitla, Atetelco, Las Calaveras, Cuanalan, Barrio de los Comerciantes (Rattray and Civera Cerecedo, 2003), La Ventilla (Gómez Chavez, 2000), Tlamimilolpa, Tlailotlacan or Oaxaca Barrio (Spence and Gamboa Cabezas, 2003; Ortega Cabrera, 2014), and Tlajinga (Storey and Widmer, 2003). These rural settlements or barrios, also known as ethnic enclaves, were a part of the greater Teotihuacan society. Presumably, these barrios were defined by a form of organization into categories that contained different sectors, such as political, economic, corporate, ethnic, and domestic areas for families; these may or may not have shared the same cultural traditions as other inhabitants in the city (Millon, 1973). These sites were used in the archaeological interpretation of materials located in domestic places for family, political, religious, and socioeconomic integration activities. Nevertheless, archaeological data do not support the current knowledge on this complex barrio structure, nor has genetic homogeneity been proven (Ortega Cabrera, 2014).

Thus far, ancient DNA (aDNA) analysis has allowed reconstructing a part of the genetic history of ancient populations. Because of its maternal heritage, mitochondrial DNA (mtDNA) extracted from osseous samples provides a potential source of genetic evidence. The use of mtDNA has an advantage in aDNA studies since the molecule itself is contained in numerous mitochondria within the cell, which increases the likelihood of obtaining DNA from preserved bone material despite taphonomic action. The aDNA is always scarce and degraded, and to be extracted under strict conditions to avoid contamination from modern DNA. In Mexico, genetic studies of pre-Hispanic populations are scarce (Merriwether, 1994; González-Oliver, 2001; Kemp et al., 2005; De la Cruz et al., 2008; Solórzano Navarro et al., 2009; Álvarez-Sandoval et al., 2014, 2015). All samples showed the vari- 
ation expected for Amerindian mtDNA, analyzed in most of the cases using restriction enzymes over amplified DNA to generate restriction fragment length polymorphisms (RFLP) characteristic of each of the mtDNA haplogroups (Wallace et al., 1985). Historically, such polymorphism studies carried out around the world have been focused on research of the peopling of the Americas (Wallace et al., 1985; Shurr et al., 1990; Torroni et al., 1993; Stone and Stoneking, 1993; Merriwether et al., 1994), population expansion by language family (Monroe et al., 2013), and human dispersal out of Africa (Behar et al., 2008).

In this research, aDNA analysis helped to characterize the three households at the Teotihuacan Valley through mtDNA recovered from burials in San Francisco Mazapa, San Sebastián Xolalpan. Remains of human bone material used to manufacture tools in La Ventilla were also utilized to characterize this barrio. We investigated multiethnicity among households during the Middle Horizon in Teotihuacan, based on the 2000 architectonic corporative structures established in the city (Millon, 1973), and subsequent demographic changes during its hegemony. Archaeological data provided evidence of population growth and integration with other regions in Mexico, thus making it possible to predict genetic variation within the city.

\section{MATERIALS AND METHODS}

\section{Samples}

The skeletons studied belong to a collection of pre-Hispanic individuals, which form part of the national archaeological heritage. The collection is kept under the custody of the Instituto Nacional de Antropología e Historia, which has authorized their use for study purposes.

Phalanxes and femur fragments of 11 individuals from San Francisco Mazapa's burials were examined. These burials belonged to a household located in sector N2E2 (Serrano et al., 1991) of Teotihuacan's planimetric map in central Mexico (Millon, 1973). These burials date back to the Tlamimilolpa-Xolalpan phases (250-400 AC). Fragments of radius, femur, tibia, and fibula of 8 subjects from sector N4E2 (Millon, 1973) at the San Sebastián Xolalpan household were recovered and sampled. These fragments were dated to the late Xolalpan phase. In addition, the remains of bone tool manufacturing from 20 different right femurs and one humerus were taken out from La Ventilla's pits and dumps and were also sampled. These fragments from La Ventilla, another neighborhood belonging to the Tlamimilolpa to Metepec phases, were dated between 300 to $700 \mathrm{AC}$. The samples corresponded to excavations in sectors N1W2, S1W1, and S1W2 in Teotihuacan (Gomez Chavez, 2000; Meza-Peñaloza, 2015).

A total of 111 pre-Hispanic individuals were analyzed; the origins of 75 of them are referenced in Merriwether et al. (1994), González-Oliver et al. (2001), Juárez (2002), López-Armenta (2007), Herrera-Salazar (2007), Mata-Míguez et al. (2012). In the present study, 36 Teotihuacan individuals from the Classic period (300-600 AC) and located in the Basin of Mexico were analyzed. Dating and geographical distribution are detailed in Table 1.

\section{Contamination precaution and control}

Extraction and amplification setup were conducted under standard authentication criteria for ancient DNA analysis (Pääbo et al., 2004). The spaces were physically separated in each procedure, cleaned with $10 \%$ bleach solution, 70\% alcohol, and ultraviolet (UV)-irradiated for $45 \mathrm{~min}$. Autoclaved disposable materials, gloves, mouth masks, hair covers, disposable cloths and equipment confined to the workspace were used. The solutions used were also autoclaved and UV-irradiated. Prior to eliminating any minor surface contamination, bone samples were UV-irradiated and cleaned with gentle soap, $10 \%$ bleach solution, and $70 \%$ alcohol. The clean fragments were placed in tubes with zircon beads and were homogenized in FastPrep ${ }^{\circledR}-24$ instruments (MP Biomedicals). PCR pipettors were only used for ancient DNA analyses. Aerosol-resistant barrier tips to prevent crossover were utilized and the mix for PCR preparation was performed in a cabinet with continuous airflow (or positive), filtered and UV-irradiated.

Molecular data obtained at the Anthropological Genetics Laboratory (Universidad Nacional Autónoma de México, Mexico City) were reproduced at the aDNA laboratory of the National Laboratory of Genomics for Biodiver- 


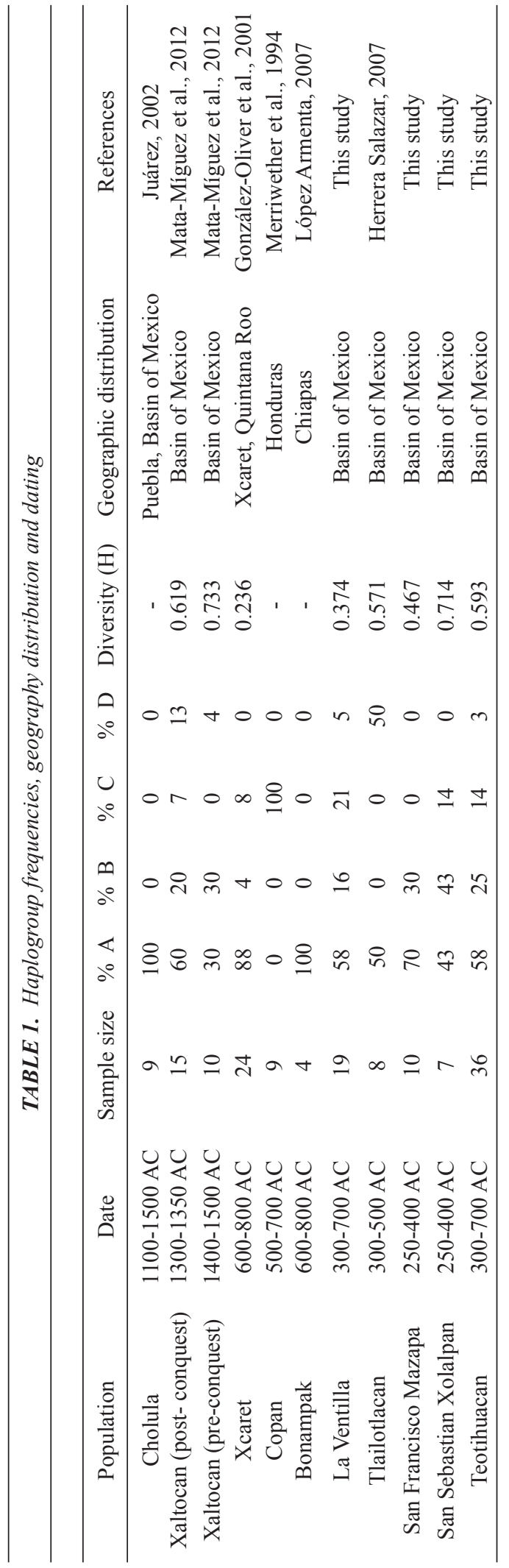

sity (CINVESTAV, Instituto Politécnico Nacional) using high-resolution melting (HRM) analysis (Álvarez-Sandoval et al., 2015) in order to authenticate aDNA results. Collagen was observed as indirect evidence of DNA survival prior to ascertaining the biochemical preservation in the bone material utilized (see Aguirre et al., 2011).

DNA extraction, amplification, and statistical analysis

Powdered samples, between 300-500mg, were digested with extraction buffer $(50 \mu l$ $0.5 \mathrm{M}$ EDTA $\mathrm{pH} 8,750 \mu \mathrm{l}$ of $10 \% \mathrm{SDS}, 200 \mu \mathrm{l}$ $20 \mathrm{mg}$ Proteinase $\mathrm{K}$ ) overnight at $37^{\circ} \mathrm{C}$ in slow agitation. Phase separation was done by centrifugation for $5 \mathrm{~min}$ at $4^{\circ} \mathrm{C}$ with shaking at $13500 \mathrm{rpm}$, followed by the GENECLEAN ${ }^{\circledR}$ procedure based on silica matrix (www.mpbio. com). The resulting pellet was dried at room temperature for $10 \mathrm{~min}$ and re-suspended in 30 $50 \mu 1$ deionizer and distilled water conditions previously reported in our laboratory (Aguirre et al., 2011).

Duplicated extracts were used for analysis of the markers that define Native American mtDNA lineage clusters (Stone and Stoneking, 1993). 5-8 $\mu 1$ of DNA extract was used in PCR reaction mixture, which contained $1 \mathrm{x}$ buffer, $1 \mathrm{mg} / \mathrm{ml} \mathrm{BSA,} 2.0 \mathrm{mM} \mathrm{MgCl} 2,200 \mu \mathrm{M}$ mix dNTP, $0.6 \mu \mathrm{M}$ each primers, $1 \mathrm{U}$ AmpliTaq Gold ${ }^{\circledR}$ polymerase (Applied Biosystems) in a total volume of $25 \mu$. Cycling had an initial denaturation step which was performed at $95^{\circ} \mathrm{C}$ for $5 \mathrm{~min}$; 60 cycles at $95^{\circ} \mathrm{C}$ for $20 \mathrm{sec}, 55^{\circ} \mathrm{C}$ (or $60^{\circ} \mathrm{C}$ in the case of Hae III site primers) for $30 \mathrm{sec}, 72^{\circ} \mathrm{C}$ for $30 \mathrm{sec}$, and an extension of $72^{\circ} \mathrm{C}$ for $10 \mathrm{~min}$. PCR products were visualized using 3\% Methaphord $®$ agarose-gel electrophoresis. RFLP analysis by enzyme digestion was done at $37^{\circ} \mathrm{C}$ for HinC II (for haplogroup C), Hae III (for haplogroup A), and Alu I (for haplogroup D). Genotypes were observed in $15 \%$ polyacrylamide gel.

For statistical analysis the sum of sample haplogroups from the San Sebastián Xolalpan, La Ventilla, and San Francisco Mazapa barrios was considered as Teotihuacan representative. Tlailotlacan was not included in the unit, since this barrio has been archaeologically described as either Oaxacan or external in origin. 
We calculated haplogroup diversity $(\mathrm{H})$ and frequencies. Hierarchical clustering of spatial frequency of the groups was constructed in the Statistica software, which was explored by Principal Components Analysis. Also, the centroid method calculated the distance between two clusters for all variables and cases; the merged cluster is a weighted combination of the centroids of the two individual clusters. Hierarchical clustering was analyzed with the algorithm K-Means Clustering (within Statistica) to calculate distance or similarity matrix between all pairs of cases. Euclidean distances between clusters were obtained.

Genetic differentiation levels between paired populations were estimated by Analysis of Molecular Variance (AMOVA), pairwise $\mathrm{F}_{\mathrm{ST}}$ distance, and Slatkin's distances with 10000 permutations using Arlequin version 3.0 (Excoffier et al., 2005). The resulting groups from the structure analysis were employed to construct a dendrogram by the UPGMA (Unweighted Pair-Group Method with Arithmetic Averaging) method using matrix distance of linearized $\mathrm{F}_{\mathrm{ST}}$.

The estimated rates of gene flow for the 10 population comparisons were computed, the matrix was based on of previous matrix of Slatkin's linearized $\mathrm{F}_{\mathrm{ST}} \mathrm{t} / \mathrm{M}=\mathrm{F}_{\mathrm{ST}} /\left(1-\mathrm{F}_{\mathrm{ST}}\right)$, where two populations of size $\mathrm{N}$ exchange a fraction $\mathrm{m}$ of migrants of each generation, and mutation rate $\mathrm{u}$ is negligible compared to the migration rate $\mathrm{m}$, following equilibrium between migration and drift. Additionally, the calculated gene flow considers that only two populations exchanged migrants, whose estimator was $\mathrm{M}=\mathrm{Nm}$ for haploid populations, where $\mathrm{M}=1-\mathrm{F}_{\mathrm{ST}} / 2 \mathrm{~F}_{\mathrm{ST}}$ (Excoffier, 2006). Linear regression was calculated between $\mathrm{M}$ and geographic distance (in $\mathrm{km}$ ) in Sigma plot v.10.0. Infinite values of migration rates estimated were collocated only for graphic representation. To test the hypothesis that Teotihuacan was a multiethnic city during the Mesoamerican Classic Period and that it extended toward other parts of present-day Mexico or even Central America, we compared the samples reported from Mayan sites such as Xcaret, Copan, and Bonampak; also Cholula culture; and Tlailotlacan or Oaxaca barrio and Xaltocan (see Table 1 for references. For locations see Fig. 4).

\section{RESULTS}

The population studied comprised 36 individuals from three households from the Teotihuacan Valley.

Three of the samples were taken out of the database since it was not possible to obtain the final genotype from one of them, and for the remaining two, results could not be replicated.

Mitochondrial ancestry by standard restriction fragment RFLP for haplogroups A, B, C, D were identified: $58 \%$ assigned to A, $25 \%$ to $\mathrm{B}, 14 \%$ to $\mathrm{C}$, and $3 \%$ to D haplogroups (Table 1). The number of haplogroups was smaller in the Mazapa group with 2 variants, in contrast to La Ventilla and Xolalpan, which had 3 and 4 variants respectively; Cholula (these groups were located geographically in Central Mexico) and Copan (in Honduras) had 1, Tlailotlacan 2, Xaltocan and Xcaret (from Southeast Mexico) 3 haplogroups. The major diversity $(\mathrm{H})$ was between Teotihuacan and Xaltocan ranging between 0.593 and 0.733 , distributed in the Basin of Mexico, toward the central region of the country (Table 1).

In the Principal Component Analysis, Teotihuacan households of La Ventilla and post-conquest Xaltocan along with the total frequencies from La Ventilla/Mazapa/Xolalpan (all with 4 haplogroups) and Mazapa were closer to Xolalpan and Tlailotlacan with $50 \%$ of haplogroups A and D (Fig. 1).

The Centroid Method showed that the groups from Bonampak (at the south of Mexico), Cholula, Xcaret, Tlailotlacan, and Copan were cases distant from the center, but classified as a small cluster that included 3 cases. Xaltocan (post-conquest) and Teotihuacan, Tlailotlacan excluded, were fairly close to the centroid. Despite the dimensions registered at centroid, a principal cluster was found with algorithm KMean, clustering in 10 cases (cluster $n^{\circ} 1$ ), and a second cluster classified Copan (Table 2), whose Euclidean distances were 1 vs 2 of 0.5806 , and between cluster 2 vs 1 of 0.3371 .

Altogether these analyses showed several distinctive populations, Copan standing out for its high incidence of haplogroup C. Also, Xaltocan (pre-conquest), far from the center, was different due to its proportion of haplogroups $\mathrm{A}$ and B. Cholula and Bonampak formed a cluster 


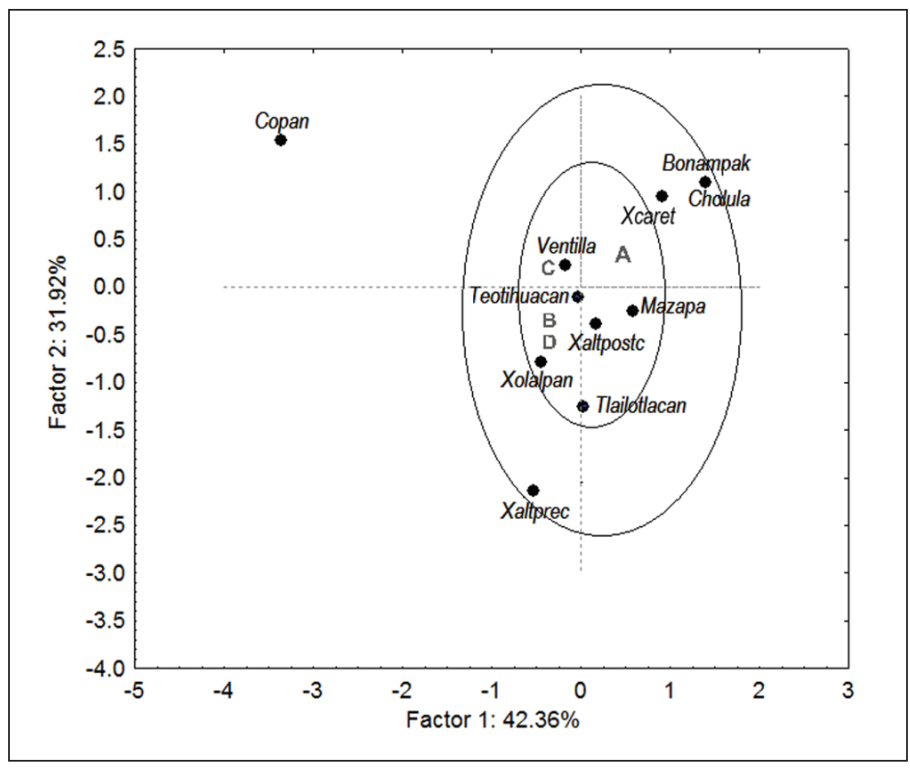

Fig. 1. Plot of principal components for the Amerindian haplogroups in 10 populations from ancient Mexico.

because of their high proportion of haplogroup A, followed by the Xcaret population.

Historical archaeological references tell us of exchange between groups from Teotihuacan and central and southern Mexico to Cen- tral America. Such hypothesis cannot be confirmed with the current comparisons between the genetic distances, where genetic variance among groups was undetectable, and inside of proven groups there was a higher range of

TABLE 2. Cluster analysis with Centroid Methods and K-Means clustering between cases

\begin{tabular}{cccc}
\hline Cases & $\begin{array}{c}\text { Principal Factor } \\
(\text { Centroid })\end{array}$ & $\begin{array}{c}\text { Distance from cluster center } \\
(k \text {-mean }) \\
\text { Cluster 1 }\end{array}$ & $\begin{array}{c}\text { Distance from cluster center } \\
(k \text {-mean }) \\
\text { Cluster 2 }\end{array}$ \\
\hline La Ventilla & -0.180 & 0.088 & - \\
Mazapa & 0.099 & 0.094 & - \\
Bonampak & 0.862 & 0.201 & - \\
Tlailotlacan & -0.692 & 0.228 & - \\
Xcaret & 0.525 & 0.140 & - \\
Xolalpan & -0.645 & 0.186 & - \\
Teotihuacan & -0.197 & 0.079 & - \\
Cholula & 0.862 & 0.201 & - \\
Xaltocan (post- & 0.103 & 0.034 & - \\
conquest) & & 0.241 & 0 \\
Xaltocan (pre-conquest) & -0.038 & - & \\
Copan & -2.082 & & \\
\hline
\end{tabular}


77.23 and 80.59 percent of variation (Table 3 ). The pairwise $F_{S T}$ results showed structure population between Teotihuacan, central and southern Mexico groups $\left(\mathrm{F}_{\mathrm{ST}}=0.228\right.$ versus $\mathrm{F}_{\mathrm{ST}}=0.194, p=0.00$, Table 3). Structure analysis detected significant differences between 2 groups, which accounted for $1.64 \%$ of the genetic variance; whilst subgroups within groups explained $17.7 \%$. In this second analysis, Bonampak was removed due to its inconveniently small $\mathrm{N}$, and because the variation between groups was negative (point 1 in Table 3 ).

A dendrogram constructed by UPGMA with $\mathrm{F}_{\mathrm{ST}}$ values showed the arrangements of populations (Fig. 2) with the same hierarchical clustering among distances with a difference between Copan and the rest of the cases. Genetic distance analysis grouped Mayans from the Xcaret and Cholula populations followed by other branches that divided into Teotihuacan and Xaltocan (post-conquest) groups, suggesting migrations into Teotihuacan due to the dominant role the city held during the Classic Period and because of population movements occurring in the Post-Classic Period around the valley of Mexico. In contrast, Mayans from Copan showed a higher genetic distance (Fig. 2) indicating a modest relationship with Teotihuacan.

To try to understand the genetic distance found, we estimated the number of migrants $(\mathrm{Nm})$ between the populations studied. The estimate comparisons of gene flow for 10 populations are given in Table 4. Some infinite values were noted, indicating higher $\mathrm{Nm}$, where gene flow exceeded any effects of genetic drift decreasing the differentiation, as was the case of the comparisons of Mazapa vs. Xolalpan, Mazapa vs. La Ventilla $(p<0.01)$, Xolalpan vs. La Ventilla ( $p=0.028)$, and Xaltocan (post-conquest) with La Ventilla/Xolalpan/Mazapa. Another higher Nm was between Xcaret/ Cholula $(p<0.02)$. Also, higher values were obtained between the populations from Xaltocan (post-conquest) and Xcaret /Tlailotlacan $(\mathrm{Nm}>4, p=0.07)$, Xcaret vs. Mazapa $(p=0.07)$, Maya vs. La Ventilla $(p<0.01)$, Xaltocan (preconquest) vs. La Ventilla $(p<0.01)$, and Xaltocan (pre-conquest) vs. Xolalpan $(\mathrm{Nm}=19.49$, $p<0.01)$. In Table 4 , all $\mathrm{Nm}<1$ describe a low

TABLE 3. Hierarchical analysis of molecular variance (AMOVA) using different structures from the Teotihuacan groups in Mexico. Describe percent of variation

\begin{tabular}{|c|c|c|c|c|c|c|c|}
\hline & Groups & $\begin{array}{l}\text { Among } \\
\text { groups }\end{array}$ & $\begin{array}{c}\text { Among } \\
\text { populations } \\
\text { within groups }\end{array}$ & $\begin{array}{c}\text { Within } \\
\text { populations }\end{array}$ & $\mathrm{F}_{\mathrm{ST}}(\mathrm{p})$ & $\mathrm{FSC}(\mathrm{p})$ & FCT (p) \\
\hline $\begin{array}{l}\text { 1.Central } \\
\text { Mexico, and } \\
\text { South of Mexico } \\
\text { to Honduras }\end{array}$ & $\begin{array}{l}3 \text { Maya } \\
\text { populations, } \\
4 \text { Teotihuacan } \\
\text { groups } \\
\text { included with } 3 \\
\text { populations from } \\
\text { Central Mexico }\end{array}$ & -8.87 & 31.65 & 77.23 & $\begin{array}{c}0.228 \\
(0.000)\end{array}$ & $\begin{array}{c}0.291 \\
(0.000)\end{array}$ & $\begin{array}{l}-0.089 \\
(0.746)\end{array}$ \\
\hline $\begin{array}{l}\text { 2.Teotihuacan, } \\
\text { Central Mexico } \\
\text { and South of } \\
\text { Mexico }\end{array}$ & $\begin{array}{l}2 \text { Maya } \\
\text { populations, } \\
4 \text { Teotihuacan } \\
\text { groups and } 3 \\
\text { populations from } \\
\text { Central Mexico }\end{array}$ & 1.64 & 17.77 & 80.59 & $\begin{array}{c}0.194 \\
(0.000)\end{array}$ & $\begin{array}{c}0.181 \\
(0.000)\end{array}$ & $\begin{array}{l}0.0164 \\
(0.241)\end{array}$ \\
\hline
\end{tabular}




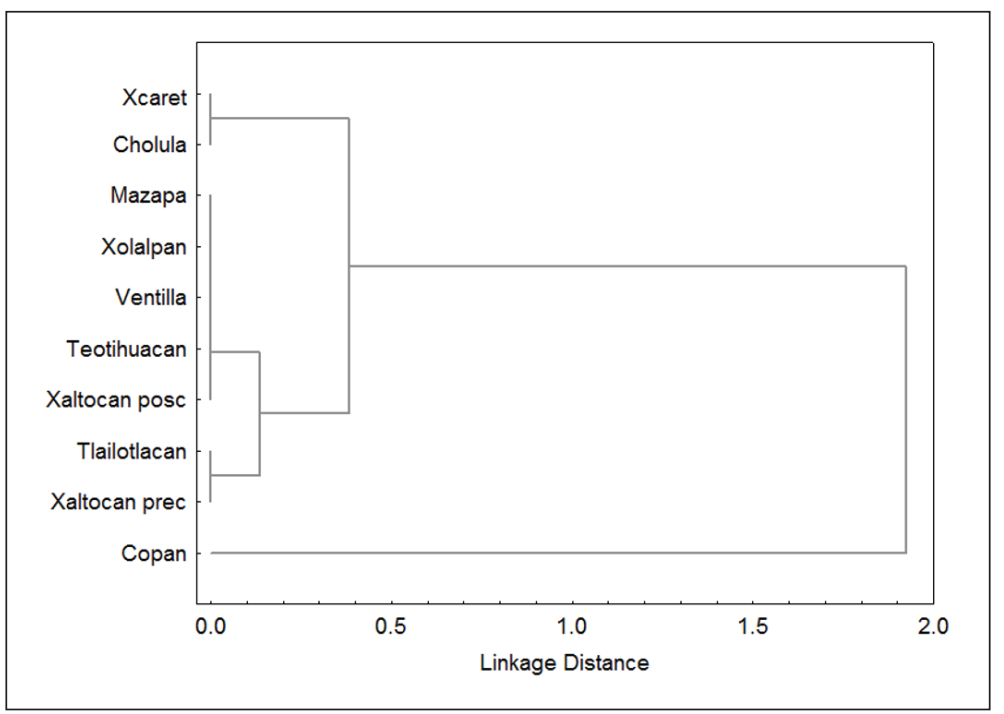

Fig. 2. Dendogram based on UPGMA of mitochondrial haplogroups' DNA for 10 populations from central and south Mexico. Xaltocan presents two data: post-conquest (postc) and pre-conquest (prec).

gene flow. Genetic drift may influence each of the populations, such as Copan and Teotihuacan (included three studied groups), Cholula and Teotihuacan groups, Xaltocan and Copan /Cholula $(p<0.01)$, Tlailotlacan with other Te- otihuacan groups ( $p=0.036$, Table 4$)$. Linear regression was calculated from 10 population comparisons depending on their geographic distance (Fig. 3). Infinite Nm values are represented by $13 \mathrm{Nm}\left(\mathrm{r}^{2}=0.12994, p<0.0001\right)$ in

TABLE 4. Mitochondrial DNA pairwise comparisons by $M=N m$-values (below diagonals) and p-values (above diagonals) between prehispanic populations from Mexico

\begin{tabular}{|c|c|c|c|c|c|c|c|c|c|c|}
\hline & 1 & 2 & 3 & 4 & 5 & 6 & 7 & 8 & 9 & 10 \\
\hline 1 & & 0.142 & 0.020 & 0.070 & 1.000 & 0.002 & 0.103 & 0.000 & 0.073 & 0.000 \\
\hline 2 & 0.111 & & 0.429 & 0.801 & 0.210 & 0.020 & 0.359 & 0.073 & 0.717 & 0.000 \\
\hline 3 & $\infty$ & 0.000 & & 0.687 & 0.020 & 0.041 & 0.615 & 0.227 & 0.440 & 0.001 \\
\hline 4 & 4.868 & 0.162 & 1.933 & & 0.165 & 0.005 & 0.721 & 0.010 & 0.491 & 0.000 \\
\hline 5 & 1.150 & 0.299 & 0.676 & $\infty$ & & 0.028 & 0.151 & 0.003 & 0.194 & 0.000 \\
\hline 6 & 4.977 & 0.473 & 2.429 & $\infty$ & $\infty$ & & 0.041 & 0.315 & 0.186 & 0.000 \\
\hline 7 & 0.905 & 0.186 & 0.610 & 1.936 & 2.210 & 3.652 & & 0.036 & 0.644 & 0.000 \\
\hline 8 & 4.473 & 0.448 & 2.556 & $\infty$ & $\infty$ & $\infty$ & 2.662 & & 0.234 & 0.000 \\
\hline 9 & 4.910 & 0.323 & 2.589 & $\infty$ & $\infty$ & $\infty$ & 8.231 & $\infty$ & & 0.000 \\
\hline 10 & 0.735 & 0.309 & 0.590 & 3.000 & 19.496 & 4.084 & $\infty$ & 3.862 & 10.223 & \\
\hline
\end{tabular}

1: Xcaret, 2: Copan, 3: Cholula, 4: Mazapa, 5: Xolalpan, 6: La Ventilla, 7: Tlailotlacan, 8: Teotihuacan, 9: Xaltocan (post-conquest), 10: Xaltocan (pre-conquest). $\infty$ are infinite values. Bold numbers indicate significant values since comparison between the study groups. 


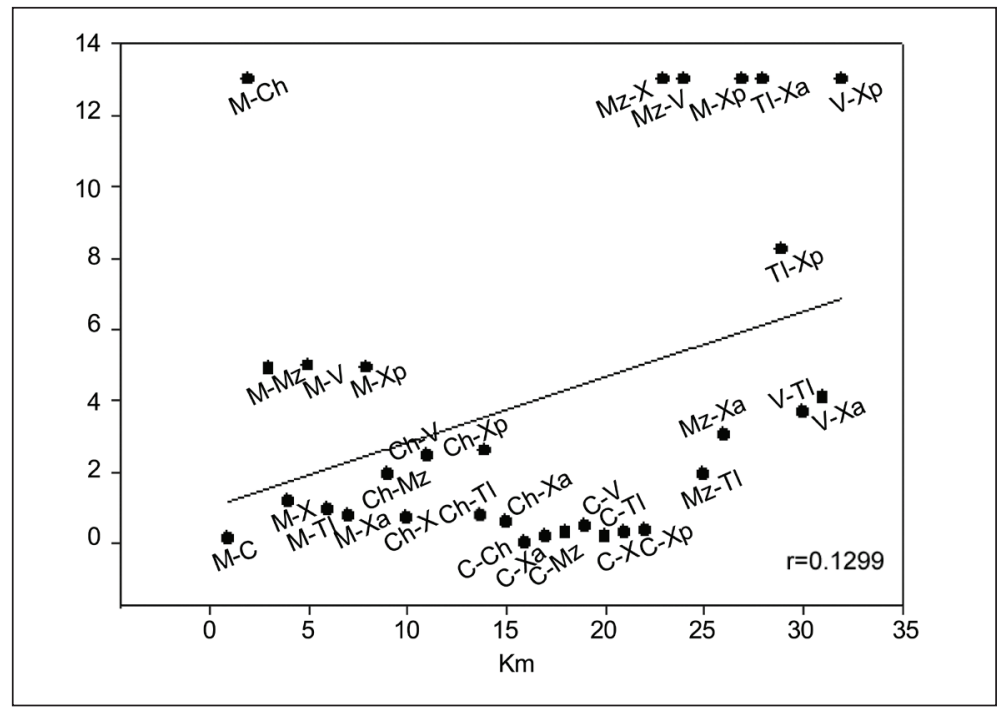

Fig. 3. Number of migrants estimated by geographic distance among the 10 populations compared. A linear regression analysis can be observed; populations'names of pairwise comparisons are M:Maya (from Xcaret), Ch:Cholula, V:Ventilla, Mz:Mazapa, Tl:Tlailotlacan, X:Xolalpan, Xa:Xaltocan (pre-conquest), Xp:Xaltocan (post-conquest).

the graph. There was no correlation between geography and number of migrants.

\section{DISCUSSION}

Genetic variation was identified in $\mathrm{La}$ Ventilla, San Francisco Mazapa, and San Sebastián Xolalpan households, and it is evidenced by the distributions of haplogroup frequency. In the case of La Ventilla, the sample comes from remains of bones used as tools, which could represent the group, given that previous studies were able to demonstrate that bones turned into artifacts belonged to inhabitants from this barrio (Meza Peñaloza, 2015). Also, through stable isotope analysis, it was found that such materials presented a local dietary consumption (Arnaud, 2014).

Residential compounds showed to be composed by distinctive groups across the populations compared. Despite this, similar haplogroup frequencies as those observed in Teotihuacan (Table 1) have been reported throughout Mexico, and are maintained in present day (A-50\%, B-24\%, C-18\%, D-8\%), even though regional differences may be variable (Gonzalez-Sobrino et al., 2015). Principal Component Analysis showed closeness be- tween the rural residents of the three barrios studied. Tlailotlacan did not group close in the cluster formed by La Ventilla-MazapaXolalpan-Xaltocan, but it was part of a larger cluster of 10 cases, which could be visualized as a different residence compound with partial integration in Teotihuacan.

The analysis of population structure found a small molecular variance among groups. It was possible to observe a slight genetic differentiation within the three studied groups, suggesting that migration and genetic drift could lead to a more effective role between the groups.

Genetic distance analysis identified two important branches: the first linked Mayans from the Xcaret and Cholula populations, suggesting ancient relationships; the second branch grouped the three households studied with post-conquest Xaltocan; a third, small branch contained Tlailotlacan and pre-conquest Xaltocan (Fig. 2). The suits of cluster analyses showed links formed between $\mathrm{La}$ Ventilla-Mazapa-Xolalpan, suggesting a pronounced population dynamic in Teotihuacan during the Classic Period in the Basin of Mexico and regions such as Xcaret in Quintana Roo. 
Archaeological interpretations have showed that the different households shared religious, government, commercial, and burial activities. We added genetic relations shown by the genetic distance between the Teotihuacan groups, which could correspond to the ethnic view of barrio described previously by archaeologists (Millon, 1973).

Paleomigration markers or isotopic anthropology may perhaps also reflect patterns of population movements within Teotihuacan. In fact, it is possible to distinguish ethnic areas in Teotihuacan by cluster analysis of craft production, such as in Tlajinga, where elements were found to be related to other regions in Teotihuacan (Altschul, 1987). In addition, Teopancazco, another barrio from Teotihuacan, displays foreign activity from different Mesoamerican coastal regions as far as Honduras and Guatemala (Manzanilla, 2015). In the same way, sacrifices associated to the Pyramid of the Feathered Serpent have been identified by isotopic analysis as foreign in origin, maybe to demonstrate the hegemony of Teotihuacan (White et al., 2002). A previous study from other households such as Oaxaca, Cueva de las Varillas, Oztoyohualco, and Barrio de los Comerciantes showed similar migratory movements in Teotihuacan, where residence change was continuous throughout people's lives (Price et al., 2000). In all the barrios described above, as well as in the sacrificial site, evidence is directed toward identifying multiethnic features in Teotihuacan, which is consistent with lower genetic differentiation and connection between the three households studied, thus indicating integration.

Migration patterns were drawn from close to remote regions, estimated by $\mathrm{M}$ values, as an indirect method of gene flow. Statistics significance displayed a strong relation between the Teotihuacan groups of Mazapa, Xolalpan, and La Ventilla, but not of Tlailotlacan. The Oaxaca barrio has been described as a distinctive enclave within Teotihuacan, showing clear mobility from the Oaxacan region (Ortega Cabrera, 2014). Indeed, oxygen isotope analysis revealed that the Tlailotlacan barrio received immigrants from the Valley of Oaxaca, over $100 \mathrm{~km}$ away (White et al., 2004).
Pairwise comparison highlights the relation between Xaltocan (haplogroup frequencies after the conquest) and La Ventilla and Xolalpan. History provides an explanation for this connection: during the Middle Horizon, the settlement system extended over several hundred hectares, which included monumental architecture, civic-ceremonial architecture, sites of variable size, occupation in the hills, and highly populated regions spreading over the Valley of Mexico. Azcapotzalco, located to the west of the Texcoco Lake, was an important site in the Middle Horizon (Parsons, 1987). In this region, Xaltocan was situated $35 \mathrm{~km}$ north of modern Mexico City, whose demographic and genetic history was related to the Aztec conquest (Mata-Miguez et al., 2012). Accordingly, the settlement patterns that extended to the Valley of Mexico are consistent with the variability found in this study, and it may be reflected by genetic frequencies of maternal inheritance (view Table $4, p<0.01$ ).

La Ventilla and Mazapa households presented evidence of Mayan integration, especially from Xcaret, due to their mobility toward Teotihuacan $(p<0.01, p=0.07$ trend, respectively) by the estimated gene flow. Previous interpretations of Mayan ceramics found in Teotihuacan considered the interaction of both societies. Clayton (2005) identified a very important relationship, over the course of five centuries from the late Preclassic through late Classic, influencing political Mayan organization from Teotihuacan. The interaction between Teotihuacan groups and Mayans occurred in sub-regions such as Calakmul, Petén, and Tikal, but there was no direct interaction with Copan (Clayton, 2005). Lower numbers of migrants estimated between Teotihuacan and Copan were statistically tested (Table 4), confirming no connection between the two sites, as shown by the origin of the ceramics.

We found no correlation between Cholula and Teotihuacan $(p<0.01)$, but the gene flow between Mayans from Xcaret and Cholula was high. Rattray, under ceramic analysis, particularizes Cholula as a midpoint between Monte Albán (Oaxaca) and Teotihuacan (Rattray, 1987b). It is possible that the genetic 
relationship between Teotihuacan and Cholula was not exhibited at this time in history, and any relationship could have been generated due to commercial purposes, using Cholula as a midpoint in the trade route toward Teotihuacan. An unrepresentative sample could also explain the absence of a relationship.

Why did people migrate to Teotihuacan from different places in the Middle Horizon or in the Classic Period? Answering is complicated. Some current theories on why humans migrate point to a search for a more favorable scenario or a more attractive climate; other reasons include cultural or political oppression or discrimination, natural disasters or wars, and cultural motives such as similar religions and language (Norton, 2009). In this Period, subsistence activities consisted in the practice of agriculture, and the utilization of wild plants and local fauna within Teotihuacan's surrounding areas in the Basin of Mexico (McClung, 1987). Food sources were stored and their organization and control offered advantage over other places. Industry during the Patlachique, the Miccaotli and the Tlamimilolpa phases (in the Classic Period) grew rapidly. Thus, obsidian technology was necessary in commerce, and artisan workshops interchanged and exported products to Mayan areas; under this argument the obsidian industry was under the control of Teotihuacan's state power (Spence, 1987). As the center of production and distribution of obsidian, Teotihuacan was a commercially important place and culturally attractive to other regions. According to this development, it has been estimated that, at its peak during the Classic Period, there were 125000 to 200000 inhabitants in Teotihuacan (Millon, 1981), 51000 in the Valley of Oaxaca during late Monte Albán I (Kowalewski et al., 1989), and 35000 in Tikal during the late Classic Period (Sanders, 1973). Indeed, agriculture was pivotal, which conditioned Mesoamerican lifestyle and survival, promoting the gene flow between central and southern areas in Mexico (López-Austin, 1989).

A hypothesis suggests that people from Teotihuacan had arrived from other places, which is sustained by similarities in ceramics; it was the case of Tlailotlacan, part of the Zapotec enclave. Actually, the origin of Teotihuacan groups is not well known and is still a topic for discussion. What we put forward for consideration in this study is that people arrived in Teotihuacan from different places as a consequence of the boom in Mexico during the Classic Period. The Classic Period was of great importance across Mesoamerica in regions such as the Valley of Oaxaca (Blanton, 1987), Mayan sites like Peten, Tikal and Guatemala (Coe, 1972), Tlaxcala (Snow, 1972), the Atemajac Valley in the archaeological zone of Ixtepe, Zacatecas to the west of Mexico (Corona Núñez, 1972; Hers, 2014); central and northern Veracruz (Brüggemann, 2014), and the northeastern region (Michelet, 2014).

Genetic studies through ancient mitochondrial DNA have allowed drawing converging lines, which may be subject to discussion or exploration (Fig. 4). In general, these dynamic patterns appeared in ancient Mesoamerica according to archaeological data, and point to Teotihuacan being a multiethnic society. Our results support this multiethnicity; however, it is necessary to consider other households, to increase the sample size, and to perform sequencing to examine the distribution of frequencies. In the meantime, the households examined in this study showed the following: a) they seem to form a group; b) to exhibit a similar variability related to frequencies in urban groups in modern Mexico; c) and to show the same distribution observed in present-day haplogroups.

\section{CONCLUSIONS}

The results obtained in this study suggest probable gene flow due to population growth in Teotihuacan, where geographic distance was not a barrier for interchange. The ancient people of México were interrelated in economic, commercial, political, and religious contexts, which made genetic joins possible. We propose a representation of putative population movements, represented in Figure 4, during the Classic Period, where genetic distance and routes converge in Teotihuacan, suggesting multiethnicity. The contribution of the haplogroups obtained is limited, and should be taken with caution since 


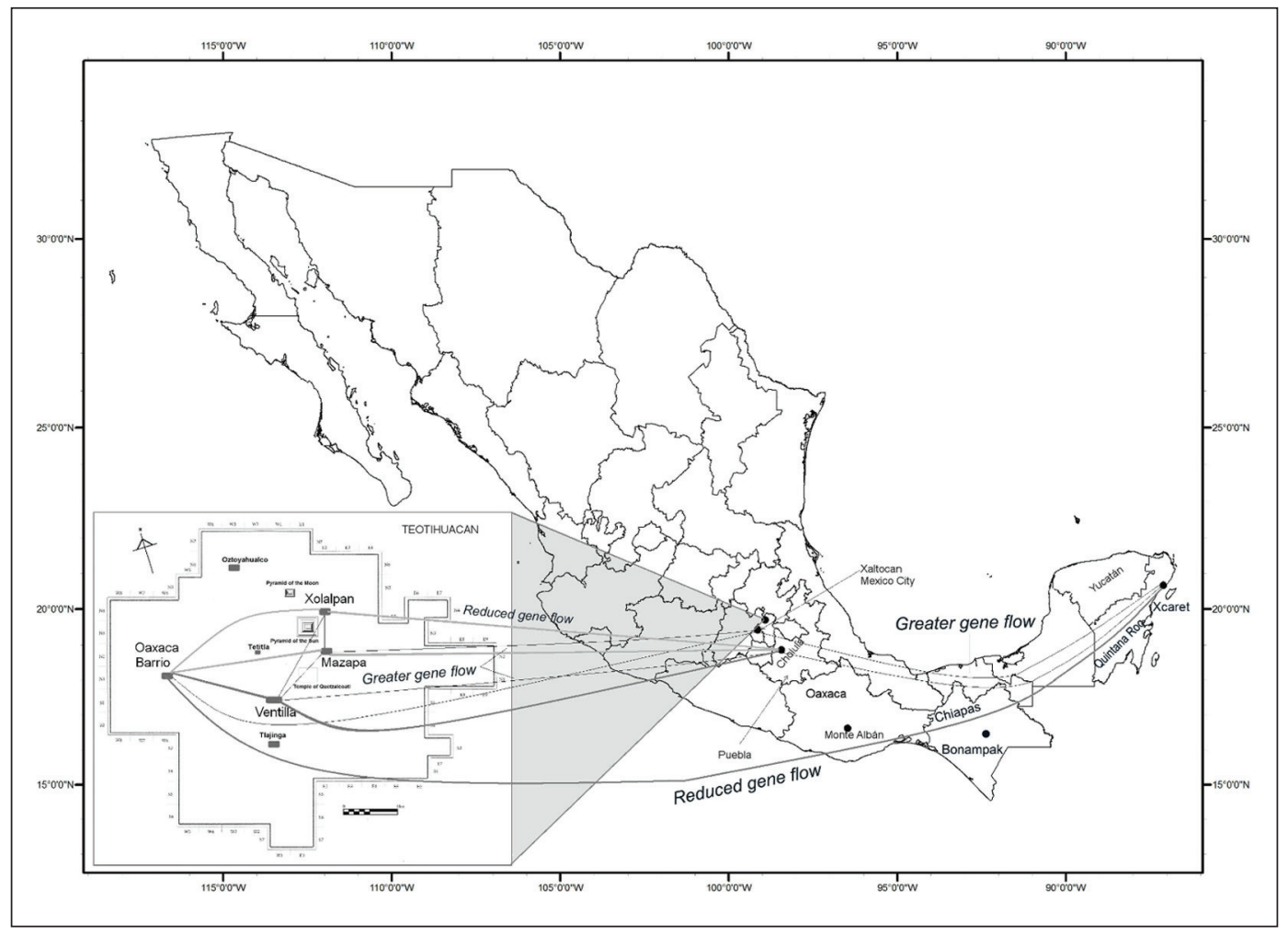

Fig. 4. Mathematical interpretation of population movements that putatively occurred during the Classic Period (300-700 AC) among indigenous groups from south and central Mexico. Routes are based upon the genetic distances and migrants estimated with M-values. It is possible that there was a route originating in the south (Mayans from Xcaret) and possibly going through Cholula, until they arrived in Teotihuacan (thin black lines); but people from Cholula had less contact with Mazapa, Xolalpan, and Tlailotlacan (thick, light gray lines) except those from La Ventilla, who could have some relationship (thick, dark gray lines). In Teotihuacan there was an interchange between the three barrios studied, except Oaxaca barrio.

they require a deeper analysis with sequences of hyper-variable regions, where the inferences made here will be corroborated.

\section{ACKNOWLEDGEMENTS}

The authors wish to thank Dr. Ruben Cabrera for allowing the access to bone materials from La Ventilla site in Teotihuacan.

\section{LITERATURE CITED}

Aguirre Samudio AJ, González Sobrino BZ, Solís Arrieta L, Terrazas Mata A, Daneels Verriest A, Serrano Sánchez C, Meza Peñaloza A, Ramírez Castilla G. 2011. Estandarización de metodologías de ADN antiguo y sus aportaciones al estudio biocultural de poblaciones prehispánicos. Anales de Antropología 45:33-50.

Álvarez-Sandoval BA, Manzanilla LR, Montiel R.
2014. Sex determination in highly fragment human DNA by high-resolution melting (HRM) analysis. PLoS ONE 9, e104629 1-6. doi:10.1371/ journal.pone.0104629

Álvarez-Sandoval BA, Manzanilla LR, GonzálezRuiz M, Malgosa A, Montiel R. 2015. Genetic evidence supports the multiethnic character of Teopancazco, a neighborhood center of Teotihuacan, Mexico (AD 200-600). PLoS ONE 10: e 0132371. doi:10.1371/journal.pone.0132371

Altschul J. 1987. Social districts of Teotihuacan. In: McClung, E., Rattray E. editors. Teotihuacan. Nuevos datos, nuevas síntesis, nuevos problemas. México: Universidad Nacional Autónoma de México. p 191-217.

Arnaud-Salas M. Procedencia y dieta de una muestra ósea de La Ventilla 92-94, Teotihuacan. 2014. Thesis for Master's Degree. Universidad Nacional Autónoma de México. México.

Behar D, Villems R, Soodyall H, Blue-Smith J, Pereira L, Metspalu E, Scozzari R, et al. 2008. The dawn of human matrilineal diversity. Am J Hum Genetics 82:1130-1140. 
Blanton RE. 1987. El florecimiento del Clásico en el Valle de Teotihuacan. In: Mountjoy J, Brockington D, editors. El auge y la caída del Clásico en el México Central. México: Universidad Nacional Autónoma de México. p 77-85.

Brüggemann J. 2014. La zona del Golfo en el Clásico. In: Manzanilla L, López Luján L, editors. Historia Antigua de México. El Horizonte Clásico. IIA. Universidad Nacional Autónoma de México. MAPorrúa. p 13-46.

Clayton S. 2005. Interregional Relationships in Mesoamerica: Interpreting Maya Ceramics at Teotihuacan. Lat Am Antiq 16:427-448.

Coe WR. 1972. Cultural contact between the lowland Maya and Teotihuacan as seen from Tikal, Peten, Guatemala. In: Teotihuacan. XI Mesa redonda. México: Sociedad Mexicana de Antropología. p 257-271.

Corona Nuñez J. 1972. Los teotihuacanos en el Occidente de México. In: Teotihuacan. XI Mesa redonda. México: Sociedad Mexicana de Antropología. p 253-256.

Excoffier L, Laval G, Schneider S, 2006. An Integrated Software Package for Population Genetics Data Análisis. URL: http://cmpg.unibe.ch/software/arlequin3

Gómez Chávez S. 2000. La Ventilla un barrio de la antigua ciudad de Teotihuacan. Degree Thesis. Escuela Nacional de Antropología e Historia.. Mexico

González-Oliver A, Márquez-Morfín L, Jiménez JC, Torre-Blanco A. 2001. Founding Amerindian mitochondrial DNA lineages in ancient Maya from Xcaret, Quintana Roo. Am J Phys Anthropol. 116:230-235.

González-Sobrino BZ, Pintado-Cortina AP, Sebastián-Medina L, Aguilar Y, Chávez-Benavides J, Carrillo-Rodríguez A, Morales-Mandujano F, Contreras AV, Silva-Zolezzi I, Medrano-González L. 2016. Genetic diversity and differentiation in urban and indigenous population of Mexico: Patterns of mitochondrial DNA and Y-chromosome linages. Biodemog Soc Biol. 62: 1-20. doi:10.108 0/19485565.2015.1117938

Herrera Salazar A. 2007. Estudio genético poblacional de restos óseos prehispánicos de una subpoblación de Teotihuacan, México. Degree Thesis. CINVESTAV. México.

Juárez Martín AI. 2002. Parentesco Biológico entre los pobladores prehispánicos de Cholula, mediante el análisis molecular de sus restos óseos. Degree Thesis. Escuela Nacional de Antropología e Historia. México.

Kemp B, Reséndez A, Román Berrelleza J, Malhi R, Glenn Smith D. 2005. An analysis of ancient Aztec mtDNA from Tlatelolco: Pre-Columbian relations and the spread of Uto-Aztecan. In: Reed DM, editors. Biomolecular Archaeology: Genetic Approach to the Past. Center for Archaeological Investigations. Occasional Paper No 32, Board of Trustees. Illinois: Southern Illinois University. p 22-39.

Kowalewski SA, Feinman GM, Finsten L, Blanton RE, Nicholas LM. 1989. Monte Albán's hinterland: Part II. Prehispanic settlement patterns in Tlacolula, Etla, and Ocotlan, The Valley of Oaxaca, Mexico (Vol. 23). Memories of the University of Michigan Museum of Anthropology. Ann Arbor: University of Michigan.

Kurtz D. 1987. The economics of urbanization and state formation at Teotihuacan. Curr Anthropol. 28: 329-353.

López Armenta M. 2007. Estudio de la estructura genética de la población prehispánica Maya del sureste de México mediante el análisis de DNA mitocondrial. Master's Thesis. Universidad Autónoma de la Ciudad de México. México.

López Austin A, López Lujan L. 2010. El pasado indígena. México: El Colegio de México.

McClung E. 1987. Patrones de subsistencia urbana en Teotihuacan. In: McClung E, Rattray E, editors. Teotihuacan. Nuevos datos, nuevas síntesis, nuevos problemas. México: Universidad Nacional Autónoma de México. p 79-106.

McClung E. 1987. Ecología y cultura en Mesoamerica. Mexico: Universidad Nacional Autónoma de México.

Manzanilla L. 1995. La zona del altiplano central en el clásico. In Manzanilla L, López Luján L, editors. Historia antigua de México, volumen II El horizonte clásico. INAH. México: Universidad Nacional Autónoma de México, MAPorrua. p 203-239.

Manzanilla L. 2015. Cooperation and tensions in multiethnic corporate societies using Teotihuacan, Central Mexico, as a case study. PNAS 112:9210-9215. doi:10.1073/pnas.1419881112.

Mata-Míguez J, Overholtzer L, Rodríguez-Alegría E, Kemp BM, Bolnick DA. 2012. The genetic impact of Aztec Imperialism: ancient mitochondrial DNA evidence from Xaltocan, Mexico. Am J Phys Anthropol 149:504-516. doi:10.1002/ ajpa. 22152

Merriwether DA, Rothhammer F, Ferrel RE. 1994. Genetic variation in the New World: ancient teeth, bone, and tissue as sources of DNA. Experientia 50:592-601.

Meza Peñaloza A. 2015. Afinidades biológicas y contextos culturales en los antiguos teotihuacanos. IIA-UNAM. México: Universidad Nacional Autónoma de México.

Michelet D. 2014. La zona nororiental en el Clásico. In: Manzanilla L, López Luján L, editors. Historia Antigua de México. El Horizonte Clásico. IIA, UNAM, México: Universidad Autónoma de México. MAPorrúa. p 241-263.

Millon R. 1973. Urbanization at Teotihuacan, Mexico, Teotihuacan Mapping Project, part one, text part two. Austin: Texas University Press.

Millon R. 1981. Teotihuacan: City, state and civilization. In: Sabloff VB, editor. Handbook of Middle American Indians, supplements I. Archaeology. Austin: University of Texas Press. p 125-135.

Monroe C, Kemp B, Smith DG. 2013. Exploring prehistory in the North American Southwest with mitochondrial DNA diversity exhibited by Yumans and Athapaskans. Am J Phys Anthropol 150: 618-631. doi:10.1002/ajpa.22237

Northon W. Human Geography. 2009. Seven edition. Oxford University Press, Canada.

Pääbo S, Poinar H, Serre D, Jaenicke-Després V, Hebler J, Rohland N, Kuch M, Krause J, Vigilant L, Hofreiter M. 2004. Genetic analyses from ancient DNA. Ann Rev Genetics 38:645-79.

Parsons JR. 1987. El área Central de Teotihuacan. Patrones regionales de colonización en el Valle de México. In: Mountjoy J, Brockington D, editors. El auge y la caída del Clásico en el México Cen- 
tral. México: Universidad Nacional Autónoma de México. p 37-75.

Price TD, Manzanilla L, Middleton WD. 2000. Immigration and the ancient City of Teotihuacan in Mexico: a study using strontium isotope ratios in human bone and teeth. J Archaeol Sci 27:903913. doi:10.1006/jasc.1999.0504

Ortega Cabrera V. 2014. La presencia oaxaqueña en la Ciudad de Teotihuacan durante el Clásico. Doctoral Thesis. Universidad Nacional Autónoma de México. México.

Rattray E. 1987a. Evidencia cerámica de la caída del Clásico en Teotihuacan. In: Mountjoy J, Brockington D, editors. El auge y la caída del Clásico en el México Central. Universidad Nacional Autónoma de México. México. p. 77-85.

Rattray E. 1987b. Los barrios foráneos de Teotihuacan. In: McClung E, Rattray E, editors. Teotihuacan. Nuevos datos, nuevas síntesis, nuevos problemas. Universidad Nacional Autónoma de México. México. p 243-273.

Ratrray E. 1997. Entierros y ofrendas en Teotihuacan. Excavaciones, inventario, patrones mortuorios. IIA, Universidad Nacional Autónoma de México. México.

Ratrray E, Civera Cerecedo M. 2003. Los entierros del Barrio de los Comerciantes. In: Manzanilla L, Serrano C. Prácticas funerarias en la ciudad de los dioses. Los enterramientos humanos de la antigua Teotihuacan. IIA. México: Universidad Nacional Autónoma de México. p 149-172.

Rodríguez Manzo V. 2003. Historia de las exploraciones. In: Manzanilla L, Serrano C, editors. Prácticas funerarias en la ciudad de los dioses. Los enterramientos humanos de la antigua Teotihuacan. IIA México: Universidad Nacional Autónoma de México. p 13-34.

Sanders W. 1965. The cultural ecology of the Teotihuacan Valley, a preliminary report of the results of the Teotihuacan Project. Pennsylvania: Pennsylvania State University.

Serrano C, Jiménez R, Villanueva M, Martínez E. 1991. Prácticas mortuorias teotihuacanas. Nuevos datos. Revista Mexicana de Estudios Antropológicos 36:143-150.

Solórzano Navarro E, Díaz N, Montiel R, Malgosa A. 2009. Análisis del ADN mitocondrial de tres series antiguas mexicanas. Estudios de Antropología Biológica 14(1):243-259.

Snow DR. 1972. Classic Teotihuacan influences in north-central Tlaxcala. In: Sociedad Mexicana de Antropología, editor. Teotihuacan. XI Mesa redonda. México. p 245-251.

Spence M. 1987. La evolución del sistema de producción de obsidiana en Teotihuacan. In: Mountjoy J, Brockington D, editors. El auge y la caída del Clásico en el México Central. México: Universidad Nacional Autónoma de México. p 87-128.

Spence M, Gamboa Cabezas LM. 2003. Mortuary practices and social adaptation in the Tlailotlacan enclave. In: Manzanilla L, Serrano C, editors. Prácticas funerarias en la ciudad de los dioses. Los enterramientos humanos de la antigua Teotihuacan. IIA. México: Universidad Nacional Autónoma de México. p 173-202.

Schurr TG, Ballinger SW, Gan Y-Y, Hodge JA, Merriwether DA, Lawrence DN, Knowler WC, Weiss KM, Wallace DC.1990. Amerindian mitochondrial DNAs have rare Asian mutations at high frequencies, suggesting they derived from four primary maternal lineages. Am J Hum Genet 46:613-623.

Stone AC, Stoneking M. 1993. Ancient DNA from a pre-Columbian Amerindian population. Am J Phys Anthropol 92:463-471.

Storey R, Widmer R. 2003. The burials of Tlajinga 33. In: Manzanilla L, Serrano C, editors. Prácticas funerarias en la ciudad de los dioses. Los enterramientos humanos de la antigua Teotihuacan. IIA. México: Universidad Nacional Autónoma de México. p 203-218.

Torroni A, Schurr T, Cabell M, Brown M, Neel J, Larsen M, Smith D, Vullo C, Wallace D. 1993. Asian affinities and continental radiation of the four founding Native American mtDNAs. Am J Hum Genet 53:563-590.

Wallace DC, Garrison K, Knowler WC. 1985. Dramatic founder effects in Amerindian mitochondrial DNAs. Am J Phys Anthropol 68:149-155.

White CD, Spence M, Longstaffe F, Stuart-Williams H, Law KR. 2002. Geographic Identities of the Sacrificial Victims from the Feathered Serpent Pyramid, Teotihuacan: Implications for the Nature of State Power. Lat Am Antiq 13:217-236. doi: $10.2307 / 971915$

White CD, Spence M, Longstaffe F, Law KR. 2004. Demography and ethnic continuity in the Tlailotlacan enclave of Teotihuacan: the evidence from stable oxygen isotopes. J Anthropol Archaeol 23:385-403. doi:10.1016/j.jaa.2004.08.002 